\title{
Effect of pre-harvest Potassium Treatment on Stem-end Rot Disease Development of Mango (Mangifera indica L.)cv. TomEJC during Fruit Ripening
}

\section{Y.M.C. Nisansala ${ }^{1}$, L.K.R.R. Jayakody ${ }^{2}$, H.A. Sarananda ${ }^{3}$ and S. Somaratne ${ }^{2}$}

${ }^{1}$ Kalutara Study Centre, The Open University of Sri Lanka, Nagoda Road, Kalutara.

2 Department of Botany, The Open University of Sri Lanka, Nawala, Nugegoda.ramanijayakody@yahoo.com

${ }^{3}$ Food Research Unit, Gannoruwa, Peradeniya.

\begin{abstract}
Mango (Mangifera indica L.) cv. TomEJC has utmost potential in export market due to its unique quality. Post-harvest disease of mango such as stem-end rot can cause considerable losses of fruits and could therefore be considered as a great threat to local and export market. This disease is controlled by application of fungicides from the time of flowering in cultivations where this disease is severe. However, the use of fungicides could lead to hazardous effects such as oncogenic risks on the consumers. Therefore, search for alternative measures for the management of stem-end rot disease is essential. In this study, an attempt was made to find out the effect of preharvest application of $\mathrm{KCl}$ on controlling stem-end rot disease development of ripe fruit. $\mathrm{KCl}$ at concentrations of $1 \mathrm{gl}^{-1}, 2 \mathrm{gl}^{-1}$ and $4 \mathrm{gl}^{-1}$ were sprayed on fruit when fruits were immature. All fruits were bagged with paper bags and fruits were harvested at the correct maturity stage. Then all fruits were inoculated with Botryodiplodia theobromae mycelial plug and allowed for natural ripening. A significant difference was observed in fruit length, fruit width and fruit volume in $\mathrm{KCl}$ - treated fruits when compared to controls. Highest fruit volume was observed in $1 \mathrm{gl}^{-1} \mathrm{KCl}-$ treated fruits and the lowest amount of total soluble solids was observed in $2 \mathrm{gl}^{-1} \mathrm{KCl}$ - treated fruits. An increase in lightness and yellowness of peel color in $\mathrm{KCl}$ - treated fruits when compared to control II (non-inoculated, non-treated) was evident, indicated by increasing $\mathrm{L}^{*}, \mathrm{~b}^{*}$ and chroma values. However, no significant difference in hue values of peel color was observed among treatments. Flesh color showed a different response to treatments and no difference in chroma value was observed among treatments. The highest $\mathrm{L}^{*}$ value and hue value was observed in $2 \mathrm{gl}^{-1} \mathrm{KCl}$ - treated fruits. Incidence and severity of stem-end rot was significantly decreased by $2 \mathrm{gl}^{-1} \mathrm{KCl}$ treatment without drastically affecting the physico-chemical properties of fruits. Vast research has shown that potassium and chloride fertility have been effective in reducing crop injury from diseases. Different mechanisms such as nutritional effects, changes of the
\end{abstract}


host-pathogen environment and production of disease inhibitory compounds could be some possible ways of action of both $\mathrm{K}$ and $\mathrm{Cl}$ in modifying disease resistance or susceptibility. Since $2 \mathrm{gl}^{-1} \mathrm{KCl}$ was able to suppress stem-end rot disease development in inoculated fruits, this concentration can be recommended as a field application to control this disease in mango variety tested after repeating the same experiment at different locations.

Keywords: Cultivar TomEJC, Botryodiplodia theobromae, post-harvest loss, stemend rot disease, disease severity, disease incidence, potassium chloride

\section{Introduction}

TomEJC Mango (Mangifera indica L.) is the world's biggest, juiciest mango. It is a beautiful golden orange fruit with an unblemished skin. It has an excellent flavor, low fibre content and smooth flesh. The fruit ripens slowly giving time for the produce to reach the market (Wijesinghe et al., 2011). TomEJC is well adapted to the dry zone in Sri Lanka. The existence of this cultivar could be identified as a new variety having distinct properties when compared to the other standard recommended Sri Lankan varieties.

Domestic and international trade of fresh mango has been limited by its perishable nature and its susceptibility to post-harvest diseases. Post-harvest diseases of mango reduce fruit quality and cause severe losses because they leave them completely unmarketable (Bally et al., 2009; Barkai-Golan, 2001; Narayanasam, 2006). Major post-harvest diseases of mango that deteriorate the fruit quality include anthracnose and stem-end rot disease ( Jefferies et al., 1990; Crane and Campbell, 1991).

Next to anthracnose, stem-end rot is considered a major problem limiting the storage and shelf life of mango fruits. Stem-end rot is a disease of importance in harvested fruit which reduces consumer acceptability. A number of fungi including Dothiorella dominicana, Phomopsis spp., Botryodiplodia theobromae and Lasiodiplodia theobromae cause stem end rot in mango (https://www.daf.qld.gov.au/plants/fruit-and.../a-z-list.../stem-end-rot). Disease symptoms develop around the stem end of the fruit as it begins to ripen after harvesting. Fungal spores are prevalent on dead leaves and twigs in orchards. As the spores spread on to flowers and fruit before harvesting, the fungi may form latent infection on fruit. Symptoms become clear as the fruit ripens. At the stem end of the fruit, brownish patches begins to develop. Due to this, both the peel and the inside flesh begins to rot. Infected fruit emanates an undesirable odour and fruit becomes unmarketable.

Post- harvest losses of fruits and vegetables that occur due to diseases in developed countries range from 5-25\%, while in developing countries it is 20$50 \%$ depending upon the commodity (Kader, 1992). However, post-harvest losses of mango accounts for around $41 \%$ of the total produce in Sri Lanka (Karunanayaka \& Adikaram, 2011). 
Control of post-harvest diseases of mango fruit mostly depends on the combination of pre and post-harvest fungicide treatment. However, increasing consumer attention on health risks and environmental hazards associated with the use of pesticides (Wilson et al., 1994), fruits and vegetables free from pesticide residues, the legislative restriction aiming at increasing food security, the development of pathogen strains resistant to few admitted postharvest fungicides and the need for high quality products have increased the search for control measures alternative to chemical fungicides (Sanzani et al., 2009).

Recently, disease control by inducing host resistance and activating the defense mechanisms in plants (especially herbaceous plants) and harvested fresh produce (Johnson \& Hofman, 2009) have been reported.

Many species of potassium-deficient plants are susceptible to frost damage and certain diseases than plants with adequate potassium levels. Increased disease resistance associated with adequate potassium levels indicate that potassium has a role in providing disease resistance and increasing the potassium levels of deficient plants have been shown to decrease the intensity of many diseases (http://en.wikipedia.org/wiki/Potassium_deficiency_\%28plants\%29).

The role of $\mathrm{K}$ in crop resistance to diseases was extensively reviewed by Perrenoud, (1990) and an inverse relationship was found between available soil $\mathrm{K}$ and the severity of disease caused by bacteria and fungi. In potatoes, $\mathrm{K}$ fertilization was found to decrease the incidence on several diseases, such as late blight (Phytophthora infestans), dry rot (Fusarium spp.), powdery scab (Spongospora subterranea) and early blight (Alternaria solani) (Perrenoud, 1990; Marschner, 1995). Potassium applications resulted in suppression of diseases such as Tikka leaf spot (Cercospora archidicola Hori.) in groundnut (Umar et al., 1997) and leaf spot disease in cotton (small brown lesions caused by Cercospora, Alternaria and Stemphylium) (Harris, 1997). Potassium fertilizers such as NPK (nitrogen-phosphorus-potassium fertilizers) applied as foliar sprays were highly effective inducers of systemic protection against powdery mildew in cucumber, mango, nectarines and grapes ( Reuveni and Reuveni, 1995 a \& 1995 b). Further, high K levels of fertilizer were shown to reduce severity of anthracnose of banana and mango in Sri Lanka (Coates, 2002-2007). High doses (three times the recommended level by Department of Agriculture) of potassium supplied as a fertilizer to soil (muriate of potash) effectively controlled stem-end rot in karutha colombon mango (Karunanayake, 2008).

In this study, an attempt was made to find out the possibility of using $\mathrm{KCl}$ as an effective agent of controlling stem-end rot disease of "TomEJC" mango. 


\section{Materials and Methods}

Mango cultivar "TomEJC" was used for this study and the experimental plot was situated at Ellawala farm, Galkiriyagama, Dambulla. Orchard management was done using standard agronomic practices recommended by Department of Agriculture, Sri Lanka (http://www.doa.gov.lk/index.php/en/ crop-recommendations/1087).

Three different concentrations of potassium chloride $(\mathrm{KCl})$ were sprayed on to mango fruits when they were at egg size (one month after fruit set in the tree). The $\mathrm{KCl}$ concentrations used were $1 \mathrm{gl}^{-1}, 2 \mathrm{gl}^{-1}$ and $4 \mathrm{gl}^{-1}$. Each concentration was sprayed once to ten mango fruits until the entire fruit was wet and the solution drained off from the fruit (approximately $10 \mathrm{ml}$ ) in three different trees. Twenty fruits on another tree which was sprayed with sterile distilled water without $\mathrm{KCl}$ served as controls (control I- non-treated, inoculated and control II-non-treated, non-inoculated). After spraying, all the treated and control fruits were labeled and covered using special paper bags (out sidebrown color, in side -black) imported from Thailand (Sarananda, unpublished data). Fruits were harvested three months after bagging and brought into the laboratory at The Open University of Sri Lanka and experiments were carried out to examine the physico-chemical properties and disease incidence/disease severity. Peel and flesh color measurements were done at the Institute of Post-harvest Technology, Anuradhapura and the determination of potassium content in the fruit peel was carried out at Horticultural Crops Research and Development Institute, Gannoruwa.

\section{Disease incidence and severity of stem-end rot disease}

Disease incidence and severity was assessed by artificial inoculation of mango fruits with Botryodiplodia theobromae. The mango fruits were surface sterilized using $70 \% \mathrm{v} / \mathrm{v}$ ethanol and washed with sterilized distilled water and air-dried in a lamina flow. Then stalks were removed and stem-ends were gently injured with a sterile scalpel. Then the injured stem-end of treated and control fruits was inoculated (plugged) with $4 \mathrm{~mm}$ diameter mycelial discs of pure culture of Botryodiplodia theobromae. Thereafter, inoculated fruits were arranged randomly in a humid chamber $\left(28{ }^{\circ} \mathrm{C}\right.$ and $\left.100 \% \mathrm{RH}\right)$. Disease incidence was recorded daily and disease severity was assessed by measuring the lesion area $\left(\mathrm{mm}^{2}\right)$ of infected fruits using a $\mathrm{mm}$ graph paper from day 5 to day 9 after inoculation (Karunanayaka and Adikaram, 2011).

\section{Physico-chemical properties}

Physico-chemical properties such as peel/flesh color, fruit volume, fruit size and total soluble solids of non-treated and treated fruits were measured after inoculation with Botryodiplodia theobromae. 


\section{Fruit size}

Fruit length (from stalk end to the apex) and width (at the widest position) were measured using a Vernier caliper (Karemera and Habimana, 2014).

\section{Fruit volume}

Fruit volume was measured using water displacement method. Fruits were dipped in a water beaker and displaced water was collected and the volume was measured using a measuring cylinder. This volume was taken as the fruit volume (Saranada, unpublished data).

\section{Total soluble solids (TSS)}

A few drops of the filtrate of diluted juice obtained from treated and control fruits were used to measure the TSS using a hand-held refractometer (modelHR-5 A022-1, Kyowa optical Co Ltd., Tokyo, Japan). The reading obtained was multiplied by a dilution factor (DF) to calculate the actual TSS content of the pulp ( $\mathrm{DF}=$ weight of sample + volume of water added/weight of sample), expressed as Brix (Sarananda \& Wijerathnam, 1994).

\section{Peel color and flesh color}

Peel color and flesh color were measured objectively using a Minolta Chromameter (Model CR-400, Minolta camera Co. Ltd., Osaka, Japan.). Physical changes in relation to peel color and flesh color were recorded in numerical notation system as $\mathrm{L}^{*}, \mathrm{a}^{*}$ and $\mathrm{b}^{*}$ where $\mathrm{L}^{*}$ indicates lightness or darkness (black-0 and white -100 ), a* ranges from negative values for green to positive values for red and $b^{*}$ ranges from negative values for blue to positive values for yellow. $\mathrm{L}^{*}, \mathrm{a}^{*}$ and $\mathrm{b}^{*}$ values were converted to hue $\left(\mathrm{h}^{0}\right)$ value and Chroma (C) (McGuire, 1992). The Chroma value $\left\{(\mathrm{C})=\left(\mathrm{a}^{* 2}+\mathrm{b}^{* 2}\right)\right.$ $\left.{ }^{1 / 2}\right\}$ indicates the strength of color. The hue value was measured as the hue angle $\left(\mathrm{h}^{0}=\right.$ arctangent $\left(\mathrm{b}^{*} / \mathrm{a}^{*}\right)$ of target color). The hue angle was expressed in degrees: $0=(\mathrm{red}), 90^{\circ}=($ Yellow $), 180^{\circ}=($ green $), 270^{\circ}=($ blue $)(\mathrm{Jha}, 2010)$.

\section{The potassium content in fruit peel}

The residual potassium content in fruit peel was measured using the dry ashing procedure. The concentration of potassium in the diluted solution was determined by the flame emission spectrophotometer using the method described by Senevirathna \& Daundasekera (2010).

Peels were obtained separately from three randomly selected fruits of each treatment and controls. Each peel sample was air- dried and ground into a fine powder in a domestic grinder. Subsequently, $0.5 \mathrm{~g}$ of each ground sample was 
ashed in a muffle furnace (Lenton thermal designs, England) at $500{ }^{\circ} \mathrm{C}$ for 4 to 5 hours until the ash turned white color. The powdery white dry ash residue obtained was wetted with $2.5 \mathrm{ml}$ concentrated nitric acid and volume was brought up to $25 \mathrm{ml}$ by adding de-ionized distilled water in a volumetric flask. The suspension was swirled for two minutes and filtered through Whatman No. 01 (5.5 cm diameter) filter paper to obtain digested (wet) samples for potassium analysis. A dilution series of the sample solutions were prepared using the above $25 \mathrm{ml}$ sample solution. One (1.0) $\mathrm{ml}$ of each sample solution was incorporated into volumetric flasks and the volume was brought up to 50 $\mathrm{ml}$ by adding de-ionized distilled water. The residual potassium content of the peel was measured using the flame emission spectrophotometer (Corning, CR 410) and was expressed as percentage potassium.

\section{Research design and statistical analysis}

Ten replicate fruits were used to assess disease incidence and disease severity, color measurement of flesh and peel, physico-chemical properties and the residual potassium content of mango peel. Data were analyzed using one-way analysis of variance (ANOVA) using SAS V. 9.2 (SAS, 2008), SPSS 16.0 (SPSS lnc., Chicago, IL, USA) to test the difference among treatments, considering all variables simultaneously and Tukey's Honest Significant Difference (HSD) Test to evaluate the level of effects for all pair-wise comparisons. Canonical Discriminate Analysis was used to represent the linear relationship of the colorimeter variables.

\section{Results}

\section{Effect of potassium on disease incidence and severity of stem-end rot disease of 'TomE JC' mango}

Disease incidence was reduced to $80 \%$ in $2 \mathrm{gl}^{-1} \mathrm{KCl}$-treated fruits and $40 \%$ in 4 $\mathrm{gl}^{-1} \mathrm{KCl}$-treated fruits (Figure 01). $1 \mathrm{gl}^{-1} \mathrm{KCl}$ was less effective than the rest of the concentrations and disease incidence was same in $1 \mathrm{gl}^{-1} \mathrm{KCl}$-treated fruits and the control fruits (control I).

Disease severity in $1 \mathrm{gl}^{-1} \mathrm{KCl}$-treated fruits was higher than control fruits (control I and II) (Table 01). The concentration of $2 \mathrm{gl}^{-1} \mathrm{KCl}-$ treated fruits showed the lowest disease severity until day 9 from the inoculation (Table 01) and in $2 \mathrm{gl}^{-1} \mathrm{KCl}$-treated fruits, the lesion development was delayed until day 7 . Therefore, $2 \mathrm{gl}^{-1} \mathrm{KCl}$ treatment is the most successful concentration to control stem-end rot disease severity than other concentrations (Table 01). 


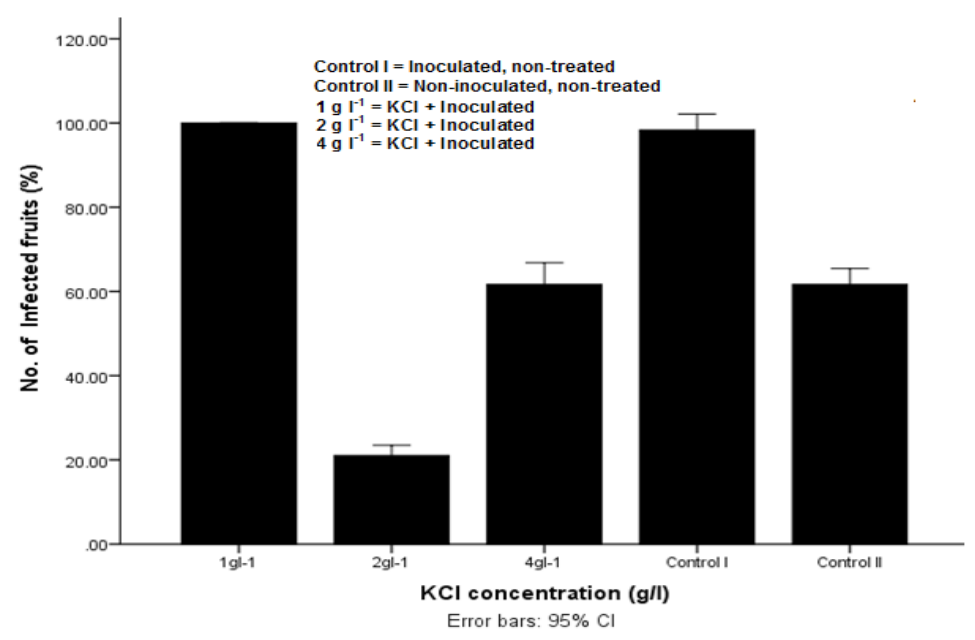

Figure 01: Effect of $\mathrm{KCl}$ on incidence of stem-end rot disease in treated and control TomEJC fruits. Values represent the mean of ten replicates with $95 \%$ confidence intervals.

Table 01: Mean lesion area $\left(\mathrm{mm}^{2}\right)$ of Stem-end rot disease (Botryodiplodia theobromae) of mango cv. TOMEJC.

\begin{tabular}{cccccc}
\hline Trt & Day 05 & Day 06 & Day 07 & Day 08 & Day09 \\
\hline Control I & $18.60^{\mathrm{ab}}(3.79)$ & $43.20^{\mathrm{ab}}(10.36)$ & $62.40^{\mathrm{a}}(16.03)$ & $77.40^{\mathrm{a}}(18.78)$ & $117.40^{\mathrm{a}}(29.14)$ \\
Control II & $10.20^{\mathrm{ab}}(4.72)$ & $13.60^{\mathrm{bc}}(6.91)$ & $70.00^{\mathrm{b}}(55.77)$ & $24.40^{\mathrm{b}}(13.85)$ & $29.20^{\mathrm{b}}(16.59)$ \\
$1 \mathrm{gl}^{-1}$ & $39.20^{\mathrm{a}}(21.63)$ & $52.20^{\mathrm{a}}(25.09)$ & $82.80^{\mathrm{a}}(22.47)$ & $108.80^{\mathrm{a}}(25.19)$ & $138.20^{\mathrm{a}}(13.28)$ \\
$2 \mathrm{gl}^{-1}$ & $(0.00)^{\mathrm{b}}(0)$ & $(0.00)^{\mathrm{c}}(0)$ & $10.60^{\mathrm{b}}(10.60)$ & $13.00^{\mathrm{b}}(13.00)$ & $13.20^{\mathrm{b}}(13.20)$ \\
$4 \mathrm{gl}^{-1}$ & $6.00^{\mathrm{b}}(2.45)$ & $8.00^{\mathrm{bc}}(3.39)$ & $10.20^{\mathrm{b}}(4.41)$ & $22.00^{\mathrm{b}}(9.17)$ & $25.00^{\mathrm{b}}(10.72)$ \\
\hline
\end{tabular}

Mean $(n=10) \pm$ Standard error. Values with the same letters in the same column are not significantly different at $(\mathrm{p} \geq 0.05)$ by Tukey's Honest Significant Difference(HSD) Test. Control I = inoculated, non-treated, Control II = non-inoculated, non-treated. Trt = Treatment $/$ control.

\section{Effect of potassium on physico-chemical properties of TomEJC' mango}

Fruit length and fruit width slightly changed with increase in $\mathrm{KCl}$ concentration (Table 02). The highest fruit volume was observed in concentration of $1 \mathrm{gl}^{-1}$ $\mathrm{KCl}$ - treated fruits and the lowest total soluble solids (TSS) was observed in $2 \mathrm{gl}^{-1} \mathrm{KCl}$ treated fruits (Table 02). The percentage of residual potassium increased with increase in $\mathrm{KCl}$ concentration. The maximum level of $\mathrm{K}$ was observed in fruits treated with $4 \mathrm{gl}^{-1} \mathrm{KCl}$ which was $(0.61+0.00)$. The percentage of residual potassium observed in control II and $2 \mathrm{gl}^{-1} \mathrm{KCl}$ - treated fruits was equal (Table 02). 
It was observed that $\mathrm{L}^{*}, \mathrm{~b}^{*}$ and chroma values for peel color of $\mathrm{KCl}$ - treated fruits showed an increase when compared to control II (non-inoculated, nontreated) indicating a slight increase in lightness and yellowness (Table 03). However, hue values for treatments and controls ranged between 86.53 to 77.17 and was not statistically significant (Table 03).

Flesh color showed a different response to treatments and no difference in chroma value was observed among treatments (Table 03). The highest L* value and hue value for flesh color were observed in $2 \mathrm{gl}^{-1} \mathrm{KCl}$ - treated fruits when compared to control fruits. Increase in $\mathrm{b}^{*}$ value for flesh color in $1 \mathrm{gl}^{-1}$ and $2 \mathrm{gl}^{-1} \mathrm{KCl}$ - treated fruits when compared to control I indicated a slight increase in yellowness in flesh.

Table 02: Changes in physico-chemical properties of mango cv. TomEJC.

\begin{tabular}{cccccc}
\hline Treatment & fruit length & fruit width & Fruit volume & TSS & K (\%) \\
\hline Control I & $13.04^{\mathrm{c}}(0.22)$ & $8.92^{\mathrm{c}}(0.15)$ & $526.00^{\mathrm{bc}}(0)$ & $14.00^{\mathrm{a}}(0)$ & $0.41^{\mathrm{ab}}(0)$ \\
Control II & $15.50^{\mathrm{a}}(0.23)$ & $9.88^{\mathrm{a}}(0.12)$ & $554.80^{\mathrm{b}}(11.36)$ & $14.00^{\mathrm{a}}(0)$ & $0.54^{\mathrm{a}}(0)$ \\
$1 \mathrm{gl}^{-1}$ & $14.62^{\mathrm{ab}}(0.37)$ & $9.88^{\mathrm{a}}(0.12)$ & $656.00^{\mathrm{a}}(23.79)$ & $14.00^{\mathrm{a}}(0)$ & $0.47^{\mathrm{b}}(0)$ \\
$2 \mathrm{gl}^{-1}$ & $14.64^{\mathrm{ab}}(0.29)$ & $9.82^{\mathrm{ab}}(0.15)$ & $625.00^{\mathrm{a}}(11.18)$ & $11.50^{\mathrm{b}}(0)$ & $0.54^{\mathrm{a}}(0)$ \\
$4 \mathrm{gl}^{-1}$ & $13.78^{\mathrm{bc}}(0.58)$ & $9.34^{\mathrm{bc}}(0.28)$ & $489.00^{\mathrm{c}}(30.10)$ & $14.00^{\mathrm{a}}(0)$ & $0.61^{\mathrm{a}}(0)$ \\
\hline
\end{tabular}

Mean $(\mathrm{n}=10) \pm$ Standard error. Values with the same letters in the same column are not significantly different at $(\mathrm{p} \geq 0.05)$ by Tukey's Honest Significant Difference (HSD) Test. Control I = inoculated, non-treated, Control II = non-inoculated, non-treated.

Table 03: Changes in $\mathrm{L}^{*}, \mathrm{a}^{*}, \mathrm{~b}^{*}$ values of peel and flesh color of mango cv.TOMEJC.

\begin{tabular}{cccccc}
\hline \multicolumn{6}{c}{ Peel Color } \\
\hline Treatment & $\mathrm{L}^{*}$ & $\mathrm{a}^{*}$ & $\mathrm{~b}^{*}$ & Chroma & Hue \\
Control I & $59.41^{\mathrm{a}}(2.09)$ & $5.24^{\mathrm{ab}}(1.41)$ & $48.57^{\mathrm{a}}(2.51)$ & $26.90^{\mathrm{ab}}(1.18)$ & $83.63^{\mathrm{a}}(1.91)$ \\
Control II & $51.25^{\mathrm{b}}(3.02)$ & $7.33^{\mathrm{a}}(0.41)$ & $34.82^{\mathrm{b}}(4.38)$ & $21.07^{\mathrm{c}}(2.19)$ & $77.17^{\mathrm{a}}(2.30)$ \\
$1 \mathrm{gl}^{-1}$ & $61.87^{\mathrm{a}}(1.09)$ & $6.48^{\mathrm{a}}(2.25)$ & $49.83^{\mathrm{a}}(2.54)$ & $28.16^{\mathrm{a}}(2.09)$ & $82.84^{\mathrm{a}}(2.26)$ \\
$2 \mathrm{gl}^{-1}$ & $58.28^{\mathrm{b}}(2.18)$ & $2.53^{\mathrm{b}}(0.22)$ & $42.68^{\mathrm{ab}}(2.89)$ & $22.60^{\mathrm{bc}}(1.43)$ & $86.53^{\mathrm{a}}(0.46)$ \\
$4 \mathrm{gl}^{-1}$ & $61.52^{\mathrm{a}}(1.03)$ & $5.28^{\mathrm{ab}}(0.45)$ & $48.78^{\mathrm{a}}(1.47)$ & $27.03^{\mathrm{ab}}(0.83)$ & $83.82^{\mathrm{a}}(0.47)$ \\
\hline
\end{tabular}

Flesh Color

\begin{tabular}{cccccc}
\hline Control I & $66.86^{\mathrm{ab}}(1.72)$ & $9.06^{\mathrm{ab}}(0.71)$ & $60.69^{\mathrm{b}}(1.22)$ & $34.88^{\mathrm{a}}(0.28)$ & $81.45^{\mathrm{b}}(0.83)$ \\
Control II & $68.72^{\mathrm{ab}}(1.48)$ & $8.80^{\mathrm{ab}}(0.99)$ & $65.79^{\mathrm{a}}(1.13)$ & $37.29^{\mathrm{a}}(0.91)$ & $82.41^{\mathrm{ab}}(0.79)$ \\
$1 \mathrm{gl}^{-1}$ & $69.70^{\mathrm{ab}}(2.25)$ & $7.63^{\mathrm{ab}}(3.29)$ & $68.07^{\mathrm{a}}(1.79)$ & $37.85^{\mathrm{a}}(2.34)$ & $83.83^{\mathrm{ab}}(2.57)$ \\
$2 \mathrm{gl}^{-1}$ & $70.42^{\mathrm{a}}(1.31)$ & $3.88^{\mathrm{b}}(1.62)$ & $65.34^{\mathrm{a}}(1.26)$ & $34.61^{\mathrm{a}}(1.38)$ & $86.69^{\mathrm{a}}(1.35)$ \\
$4 \mathrm{gl}^{-1}$ & $64.21^{\mathrm{b}}(2.71)$ & $9.60^{\mathrm{a}}(1.37)$ & $59.44^{\mathrm{b}}(0.93)$ & $34.52^{\mathrm{a}}(0.69)$ & $80.81^{\mathrm{b}}(1.36)$ \\
\hline
\end{tabular}

Mean $(\mathrm{n}=10) \pm$ Standard error. Values with the same letters in the same column are not significantly different at $(\mathrm{p} \geq 0.05)$ by Tukey's Honest Significant Difference (HSD) Test. Control I = inoculated, non-treated, Control II = non-inoculated, non-treated. 


\section{Discussion}

A considerable reduction in disease incidence was observed in $2 \mathrm{gl}^{-1} \mathrm{KCl}-$ treated fruits. The highest reduction in disease severity was also observed in $2 \mathrm{gl}^{-1} \mathrm{KCl}$-treated fruits, and the lesion development was delayed until day 7. However, $1 \mathrm{gl}^{-1} \mathrm{KCl}$ was not effective in reducing disease incidence and disease severity when compared to the rest of the concentrations tested.

$\mathrm{K}$ has been widely used to control many diseases. Vast research has shown that incidence and rate of development of diseases may be reduced by an adequate and balanced mineral nutrition in many crops. In particular, $\mathrm{K}$ and $\mathrm{Cl}$ fertility have been effective in reducing crop injury from diseases (Magen and Imas, 2004). Potassium fertilizers such as (NPK) applied as foliar sprays were highly effective inducers of systemic protection against powdery mildew in cucumber, mango, nectarines and grapes ( Reuveni and Reuveni, 1995 a \& 1995 b) and high doses (three times the recommended level by Department of Agriculture) of potassium supplied as a fertilizer to soil (muriate of potash) effectively controlled stem-end rot in Karutha Colombon mango (Karunanayake, 2008).

According to Cooke et al. (1997), pre-harvest trunk injection of potassium phosphonate when fruits were hen-egg-size and injection of $400 \mathrm{~g}$ potassium phosphonate/litre $\left(15 \mathrm{ml} / \mathrm{m}\right.$ canopy diameter) after storage at $22{ }^{\circ} \mathrm{C}$ for 20 days significantly reduced post-harvest stem-end rot (caused by Dothiorella dominicana and Phomopsis mangifera) in fruits of cultivar Kensington Pride.

The mechanisms involved with increased host resistance and potassium include a decreased cell permeability and decreased susceptibility to tissue penetration. Silica, which is accumulated in greater quantities when adequate potassium is present, is incorporated into cell walls, strengthening the epidermal layer which functions as a physical barrier to pathogens. Potassium has also been implicated to have a role in the proper thickening of cell walls (Datnoff et al., 2007).

It has been found that for many species, potassium-deficient plants are more susceptible to frost damage and certain diseases han plants with adequate potassium levels. Increased disease resistance associated with adequate potassium levels indicates that potassium has a role in providing disease resistance, and increasing the potassium levels of deficient plants have been shown to decrease the intensity of many diseases. In agriculture, some cultivars are more efficient at $\mathrm{K}$ uptake due to genetic variations and often these plants have increased disease resistance.( Datnoff et al., 2007).

Potassium deficiency has been found to be linked to diseases in a number of temperate crops (Palti, 1981) and a high K supply can improve resistance of plants to fungal and bacterial pathogens (Marscnher, 1995; Perrenoud, 1977; 
1990). The mechanism of resistance in some disease-resistant genotypes might be related to a greater efficiency in K uptake (Prabhu et al., 2007).

K-deficient plants have impaired protein synthesis and accumulate simple $\mathrm{N}$ compounds such as amides which are used by invading plant pathogens (Marschner 1995). K-deficiency increases the concentration of soluble sugars in leaf tissues providing a substrate for many pathogens (Perrenoud, 1990 ).

Further, N/K ratio may also affect disease resistance. When this ratio is too high, cells have displayed thinner cell walls and weaker membranes which are more prone to pathogen attack (Perrenoud, 1990). For similar reasons, cereals may become more prone to lodging. A low potassium/chloride $(\mathrm{K} / \mathrm{Cl})$ ratio in plant tissues, which might result from the application of chloride-containing compounds such as ammonium fertilizers, may predispose plants to disease e.g. wheat rust caused by Puccinia spp. or other diseases (Prabhu et al., 2007; Jones et al., 1989).

It is likely that the susceptibility of tropical perennial crops to some pathogens is also increased under conditions of $\mathrm{K}$ deficiency. In a study on tea plants, for example, a high K supply reduced nematode and borer damage (Muraleedharan and Chen, 1997). Another study reported that supplying K reduced Fusarium wilt in oil palm (Turner et al., 1970). However, few research studies have been conducted that could confirm a link between $\mathrm{K}$ nutrition and disease incidence or severity in tropical perennial crops.

Present study indicates that the pre-harvest application of $\mathrm{KCl}$ is effective in controlling stem-end rot disease of "TomEJC" mango. $\mathrm{KCl}$ concentration of $2 \mathrm{gl}^{-1}$ was the most effective in reducing the stem-end rot disease incidence and severity. The reduction in disease incidence and severity may be due to the production of anti-fungal compounds which in turn increase the disease resistance of cultivar 'TomEJC' and delay the appearance of post-harvest symptoms.

Further, the fruits treated with $2 \mathrm{gl}^{-1} \mathrm{KCl}$ possess residual $\mathrm{K}$ which is similar to the non-treated fruits (control II) and the lowest amount of total soluble sugar content.

$\mathrm{b}^{*}$ values for peel color of $\mathrm{KCl}$ - treated fruits showed an increase when compared to control II (non-inoculated, non-treated) indicating a slight increase in yellowness. Increase in $\mathrm{b}^{*}$ value for flesh color in $1 \mathrm{gl}^{-1}$ and $2 \mathrm{gl}^{-1}$ $\mathrm{KCl}$-treated fruits when compared to control I also indicated a slight increase in yellowness in flesh. In all treatments, hue value of flesh and peel of ripe fruits were close to $90^{\circ}$ which fall in the yellow quadrant. There is a significant difference in other parameters like fruit length, width and volume in $2 \mathrm{gl}^{-1}$ $\mathrm{KCl}$-treated fruits when compared to control I indicating a significant increase. 


\section{Conclusion}

Spraying of $\mathrm{KCl}$ at a concentration of $2 \mathrm{gl}^{-1}$ on mango fruits resulted in relatively high control of stem-end rot disease incidence and severity of 'TomE JC'. Further, the level of residues of $\mathrm{K}$ was similar to untreated controls which may not cause harmful effects on the consumer. $\mathrm{KCl}$ treatment at $2 \mathrm{gl}^{-1}$ has a significant increase in yellowness of peel and flesh, fruit length, width and fruit volume. Thus, $\mathrm{KCl}$ can be used as an alternative, safe method in controlling stem-end rot in TomEJC mango.

\section{Acknowledgement}

Mr. Tom Ellawala, Ellawala Farm, Dambulla, Mr. M.E.M.R. Palipana, Institute of Post-harvest Technology, Anuradhapura, Food Research Unit, Gannoruwa, Peradeniya and Horticultural Crop Research \& Development Institute, Gannoruwa, Peradeniya are gratefully acknowledged by the authors.

\section{References}

Bally, I.S.E., Hofman, P.J., Irving, D.E., Coates, L.M. and Dann, E.K. (2009) The effects of nitrogen on post-harvest disease in mango (Mangifera indica L. 'Keitt'). Acta Horticulturae, 820, pp 365-370. DOI:http:// dx.doi.org/10.17660/actahortic.2009.820.42

Barkai-Golan, R. (2001) Post-harvest Diseases of Fruits and Vegetables, Development and Control Amsterdam: Elsevier. DOI: http://dx.doi. org/10.1016/b978-044450584-2/50009-5

Coates, L. (2002-2007) Management of post-harvest diseases of sub-tropical and tropical fruits using their natural resistance mechanisms, Proceedings of research symposium on Post-harvest handling of tropical fruits organized by Australian Center for International Agricultural Research (ACIAR).

Cooke, A.W, Johnson, G.I., Farungsang, U. and Farungsang, N. (1997) Evaluation of phosphonate for control of post-harvest pathogens. Acta Horticulturae, 455, pp. 755-761. DOI: http://dx.doi.org/10.17660/ actahortic.1997.455.96

Crane, J.H. and Cambell, C.W. (1991) The Mango. Fact Sheet FC-2. Florida Coorporative Extension Service, University of Florida, Institute of Food and Agricultural Services, Gainesville, Florida.

Datnoff, L.E., Rodrigues F.A. and Seebold K.W. (2007) 'Silicon and plant disease' in Mineral Nutrition and Plant Disease, Datnoff, L.E., Elmer, W.H. and Huber, D.M. (eds.) St. Paul, MN, USA: The American Phytopathological Society. DOI: http://dx.doi.org/10.2478/v10045-0080016-7 
Harris, G. (1997) Potassium deficiency in cotton linked to leaf spot disease. Better Crops, 81,pp. 10-11.

Jeffries, P., Dodd, J.C., Jeger, M.J. and Plumbley, R.A. (1990) The biology and control of Colletotrichum species on tropical fruit crops. Plant Pathology, 39, pp. 343-366. DOI: http://dx.doi.org/10.1111/j.1365-3059.1990. tb02512.x

Jha, A.N. (2010) 'Color measurement and modeling' in Nondestructive evaluation of food quality: Theory and practice, Jha, A.N. (ed.), Springerverlag, Berlin Heideberg.

Johnson, G.I. and Hofman, P.J. (2009) 'Post-harvest technology and quarantine treatments' in The Mango: Botany, Production and Uses, Litz, R.E. (ed.), CABI, Wallingford, UK. DOI: http://dx.doi. org/10.1079/9781845934897.0529

Jones, P.J., Engelhard, A.W. and Woltz, S.S. (1989) 'Management of Fusarium Wilt of Vegetables and Ornamentals by Macro- and Microelement Nutrition' in Soil borne Plant Pathogens: Management of Diseases with Macro- and Microelements, Arthur W. Engelhard (ed.), St. Paul, Minn: APS press.

Kader, A. A. (1992) Post-harvest Technology of Horticultural Crops. Univ. Calif., Div. of Agric. \& Nat. Resources.

Karemera, N.J.U. and Habimana, S. (2014) Influence of pre- harvest sprays of calcium chloride on post-harvest behavior of mango fruits, cv. Alphonso. International Journal of Social Sciences and Entrepreneurship Special Issue, 2, pp. 1-13.

Karunanayaka, L.C. and Adikaram, N. K. B. (2011) Reducing post-harvest diseases of mango fruit using natural defense mechanisms. Proceedings of Annual Academic Sessions, Open University of Sri Lanka, pp. 266269.

Karunanayake, K.O.L.C. (2008) Natural defense mechanisms in mango fruit and their potential in management of post-harvest diseases. $\mathrm{PhD}$ thesis, University of Peradeniya, Peradeniya, Sri Lanka.

Magen, H. and Imas, P. (2004) Potassium chloride and suppression of diseases. Poster presented at the XVTH International Plant Protection Congress, Beijing, China.

Mango (2006). http://www.doa.gov.lk/index.php/en/croprecommendations/1087. Retrieved on 25th February 2016.

McGuire, R.G. (1992) Reporting of objective color measurements. Hort. science 27 (12), pp. 1254- 1255. 
Marschner, H. (1995) Mineral nutrition of higher plants, Academic press, San Diego, London. DOI: http://dx.doi.org/10.1016/b978-0124735422/50008-0

Muraleedharam, N. and Chen, Z.M. (1997) Pests and Diseases of Tea and Their Management. Journal of Plantation Crops, 25 (1), pp. 15-43.

Narayanasam, P. (2006) Post-harvest Pathogens and Disease Management, John Wiley and Sons, Inc., Hoboken, New Jersey.

Palti, J.(1981)Cultural Practices and Infectious Crop Diseases, Springer-Verlag, Berlin, Germany. DOI: http://dx.doi.org/10.1017/s0014479700000879

Perrenoud, S. (1977) Potassium and Plant Health. Soil Science, 127(1) pp. 63. DOI: http://dx.doi.org/10.1097/00010694-197901000-00010

Perrenoud, S. (1990) Potassium and plant health. $2^{\text {nd }}$ ed., IPI Research Topics 3, International Potash Institute, Basel, Switzerland. DOI: http://dx.doi. org/10.1007/bf02349770

Potassium_deficiency (2015). (http://en.wikipedia.org/wiki/Potassium_ deficiency_\%28plants\%29). Retrived on 27 $7^{\text {th }}$ August 2015.

Prabhu, A.S., Fageria, N.K., Huber, D.M. and Rodrigues, F.A. (2007) 'Potassium and Plant Disease' in Mineral Nutrition and Plant Disease, Datnoff, L.E., Elmer, W.H. and Huber, D.M. (eds.), St. Paul, Minn: American Phytopathological Society. DOI: http://dx.doi.org/10.2478/ v10045-008-0016-7

Reuveni, M. and Reuveni, R. (1995a)Efficacy of foliar application of phosphates in controlling powdery mildew fungus on field-grown winegrapes: effects on cluster yield and peroxidase activity in berries. J. of Phytopathology, 143, pp. 21-25. DOI: http://dx.doi.org/10.1111/j.1439-0434.1995. tb00194.x

Reuveni, M. and Reuveni, R. (1995b) Efficacy of foliar sprays of phosphates in controlling powdery mildews in field-grown nectarine, mango trees and grapevines. Crop Protection, 14, pp. 311-314. DOI: http://dx.doi. org/10.1016/0261-2194(94)00009-w

Sanzani, S.M, Nigro, F. Mari, M. and Ippolito, A. (2009) Innovations in the control of post-harvest diseases of fresh fruit and vegetables. Arab Journal of Plant Protection, 27, pp. 240-244.

Sarananda, K. H. and Wijerathnam, R. S. W. (1994). Controlled atmosphere storage of 'embul banana, Tropical Agricultural Research 6: 17-22. 
Senevirathna, P.A.W.A.N.K. and Daundasekera, W.A.M. (2010). Effect of post-harvest calcium chloride vacuum infiltration on the shelf life and quality of tomato (cv. 'Thilina'). Ceylon Journal of science (Bio. Sci.) 39(1): 35-44. DOI: http://dx.doi.org/10.4038/cjsbs.v39i1.2351

Stem-end rot (2012). (https://www.daf.qld.gov.au/plants/fruit-and.../a-z-list.../ stem-end-rot). Retrieved on $27^{\text {th }}$ August 2015.

Turner, P. D. (1970). "Some Factors in the Control of Root Diseases of Oil Palm." In Root Diseases and Soil-Borne Pathogens, edited by T. A. Tousson, R. V. Bega and P. E. Nelson, 194-200. Berkely, LA: Univ of California.

Umar, S., Debnath, G. and Bansal, S. K. (1997).Groundnut pod yield and leaf spot disease as affected by potassium and sulphur nutrition. Indian Journal of Plant Physiology 2: 59-64.

Wijesinghe, M. A. R. N., Sarananda, K. H. and Mendis, B. E. P. (2011.) The Effect of pre -harvest application of potassium on fruit quality of "TJC" mango (Mangifera indica L.) selected for processing. Proceedings of University of Peradeniya Research Sessions, Sri Lanka.

Wilson, C. L., El-Ghaouth, A., Chalutz, E., Dorby, S., Steven, C., Lu, J.Y., Khan, V. and Arul, J. (1994). Potential of induced resistance to control post-harvest diseases of fruit and vegetables. Plant Disease 78: 837-844. 